\title{
DYNAMICS AND PATTERN OF A MANAGED CONIFEROUS FOREST LANDSCAPE IN OREGON ${ }^{1}$
}

\author{
Thomas A. SPIES \\ USDA Forest Service, Pacific Northwest Research Station, Corvallis, Oregon 97331 USA

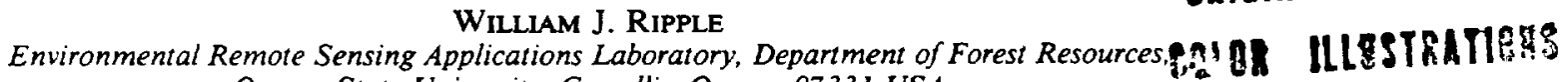 \\ Oregon State University, Corvallis, Oregon 97331 USA \\ G. A. BRADSHAW ${ }^{2}$ \\ Environmental Remote Sensing Applications Laboratory, Department of Forest Science, \\ Oregon State University, Corvallis, Oregon 97331 USA
}

\begin{abstract}
We examined the process of fragmentation in a managed forest landscape by comparing rates and patterns of disturbance (primarily clear-cutting) and regrowth between 1972 and 1988 using Landsat imagery. A $2589-\mathrm{km}^{2}$ managed forest landscape in western Oregon was classified into two forest types, closed-canopy conifer forest (CF) (typically, $>60 \%$ conifer cover) and other forest and nonforest types (OT) (typically, $<40$ yr old or deciduous forest).

The percentage of CF declined from 71 to $58 \%$ between 1972 and 1988 . Declines were greatest on private land, least in wilderness, and intermediate in public nonwilderness. High elevations $(>914 \mathrm{~m}$ ) maintained a greater percentage of CF than lower elevations $(<914 \mathrm{~m})$. The percentage of the area at the edge of the two cover types increased on all ownerships and in both elevational zones, whereas the amount of interior habitat (defined as CF at least $100 \mathrm{~m}$ from OT) decreased on all ownerships and elevational zones. By 1988 public lands contained $\approx 45 \%$ interior habitat while private lands had $12 \%$ interior habitat. Mean interior patch area declined from 160 to 62 ha. The annual rate of disturbance (primarily clear-cutting) for the entire area including the wilderness was $1.19 \%$, which corresponds to a cutting rotation of $84 \mathrm{yr}$. The forest landscape was not in a steady state or regulated condition which is not projected to occur for at least 40 yr under current forest plans. Variability in cutting rates within ownerships was higher on private land than on nonreserve public land. However, despite the use of dispersed cutting patterns on public land, spatial patterns of cutting and remnant forest patches were nonuniform across the entire public ownership. Large remaining patches $(<5000 \mathrm{ha})$ of contiguous interior forest were restricted to public lands designated for uses other than timber production such as wilderness areas and research natural areas.
\end{abstract}

Key words: clear-cutting; disturbance; edge habitat; forest management; habitat fragmentation; heterogeneity; interior habitat; landscape pattern; paichiness; remote sensing.

\section{INTRODUCTION}

Habitat fragmentation has become a major issue in forest management in recent years. Breaking large blocks of mature forest into a mosaic of young plantations, mature forests, and nonforest land has altered disturbance regimes, and contributed to loss of habitat, and reduced habitat quality for some species (Harris 1984, Lovejoy et al. 1984, Franklin and Forman 1987). Although habitat fragmentation has been recognized as one of the major classes of human impact on biodiversity and a high-priority research topic (Lubchenco et al. 1991, Soulé 1991), few studies have quantitatively characterized the process of fragmentation or

\footnotetext{
Manuscript received 16 November 1992; accepted 18 June 1993; final version received 6 August 1993.

${ }_{2}^{2}$ Present address: USDA Forest Service, Pacific Northwest Research Station, Corvallis, Oregon 97331 USA.
}

pattern development in managed forest landscapes and how the patterns and rates differ among ownerships.

For about the last $50 \mathrm{yr}$, timber on National Forest land in the Pacific Northwest has been harvested using a staggered-setting system, in which 10-20 ha clearcuts are dispersed across large areas of older forest. Franklin and Forman (1987) used a simple checkerboard cutting model to simulate the landscape structure and ecological consequences of different clear-cutting patterns. Among several models they examined, the checkerboard (staggered-setting) model created landscapes with the most edge and resulted in a rapid loss of large uncut blocks of forest. Although the results of these simple simulations have led to a call for alternative cutting patterns, few studies have examined how cutting patterns actually develop and affect edge and interior habitat conditions on National Forests (Ripple et al. 1991a). Although idealized models of landscape change 
(Franklin and Forman 1987) and conservation area design (Harris 1984) provide a useful conceptual underpinning for management, implementing the conceptual models has to begin within the constraints of current landscape patterns and trends. Characterizing current patterns and understanding how they developed may help in designing future landscapes to meet a variety of ecological objectives within these constraints.

Many ecological processes transcend ownership boundaries. Managers and scientists are struggling to develop strategies and policies that recognize ecological conditions outside their jurisdictional boundaries (Johnson and Agee 1988, Schonwald-Cox 1988, Society of American Foresters 1991). We know of no studies that have examined how cutting patterns develop on adjacent public and private ownerships. Consequently, information is lacking on the potential effects of the juxtaposition of different forest management regimes on biological diversity over large areas.

Numerous researchers have used multidate maps (Curtis 1956) and remotely sensed data to illustrate changes in forest cover over time (e.g., Nelson et al. 1987, Iverson et al. 1989, Green and Sussman 1990, Sader and Joyce 1990, Hall et al. 1991). With the exception of Hall et al. (1991) these studies have examined the pattern of conversion from forest land to nonforest land. Few studies have measured changes in spatial landscape characteristics such as patch size and amount of edge environment (Skole and Tucker 1993).

In the Pacific Northwest, management for timber production has converted large areas of old-growth and other natural coniferous forest habitat to young conifer plantations in various stages of development and patches dominated by early successional deciduous shrubs and trees. This loss of older coniferous forest has threatened the populations of the Northern Spotted Owl and other old-growth associated species (Thomas et al. 1990, Johnson et al. 1991, Ripple et al. 1991b). While considerable attention has been paid to the ecological value of natural coniferous forests and the differences between natural forest structure and plantation forest structure (Franklin et al. 1981, Spies and Cline 1988, Hansen et al. 1991) at the stand level, few researchers have characterized how the coniferous forest landscape structure has changed as a consequence of forest management (Ripple et al. 1991 a). Analyses of rates and patterns of coniferous forest landscape change are needed to better understand how management practices affect important habitat characteristics, such as amount of edge and interior habitat and patch size, and to provide a basis for making management and policy decisions that affect these ecosystems at a landscape level.

Our objectives were to: (1) Evaluate satellite imagery as a tool for monitoring and characterizing landscape change and structure in mountainous landscapes dominated by coniferous forests; (2) characterize rates of change in closed-canopy conifer forests for the 16-yr period between 1972 and 1988 ; (3) characterize changes in landscape pattern resulting from clear-cutting; and (4) contrast the pattern and dynamics of public and private forest landscapes.

\section{Study AREA}

We chose a study area where we were familiar with forest conditions from previous ground-based studies (Spies and Franklin 1991) and where we could examine a large public land planning unit (in this case the Willamette National Forest) and the private lands bordering it (Fig. 1). The study area is on the western slope of the Cascade Range in Oregon, extending from about $44.0^{\circ}$ to $44.6^{\circ}$ North Latitude and $122.0^{\circ}$ to $122.5^{\circ}$ West Longitude. The total area is 258930 ha. Elevations range from 244 to $1706 \mathrm{~m}$ above mean sea level (MSL) with slope gradients between 0 and 45 degrees. The area is primarily in the Western Hemlock (Tsuga heterophylla [Raf.] Sarg.) and Pacific Silver Fir (Abies amabilis Dougl. ex Forbes) Zones (Franklin and Dyrness 1973). Major forest tree species include Douglasfir (Psezdotsuga menziesii [Mirb.] Franco), western hemlock, Pacific silver fir, noble fir (Abies procera Rehd.), and western redcedar (Thuja plicata Donn).

The dominant timber-management objective in the area has been even-aged coniferous plantations, primarily Douglas-fir; deciduous species that establish after clear-cutting are typically reduced or eliminated through thinning and herbicide treatment on intensively managed lands. The public ownership of $\approx 70 \%$ of the study area is primarily managed by the USDA Forest Service, Willamette National Forest (Fig. 1). The Bureau of Land Management and State of Oregon make up $<10 \%$ of the total area of public lands. Private lands consist primarily of industrial land ownerships, with some areas of nonindustrial forest land.

Relatively little clear-cutting occurred on public lands until the early 1950s. Consequently, most stands $>40$ yr old regenerated naturally after wildfires, so logging primarily occurs in naturally developed forests, the majority of which are dominated by even-aged or multiple-aged conifers $100-500$ yr old. On private lands logging began earlier in the century and we estimate that about half of the closed-canopy conifer forests on these lands were natural conifer forests $50-500$ yr old in 1972. Early successional forests after fire or logging are initially dominated by evergreen and deciduous shrubs, and occasionally deciduous trees such as red alder (Alnus rubra Bong.) and big-leaf maple (Acer macrophyllum Pursh). By 25-50 yr after major disturbances, natural stands are typically characterized by closed canopies dominated by conifers. As conifer canopies close, major changes in the plant and animal communities occur and most conifer forest species begin to find suitable habitat at this stage, with the exception of old-growth habitat specialists and those species dependent on large standing dead trees (Brown 
LAND OWNERSHIP
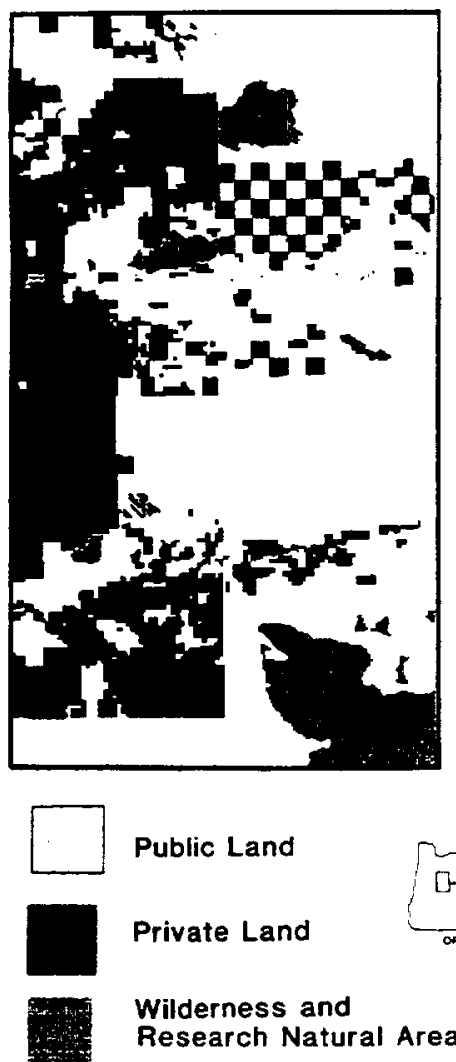

Public Land

Private Land

Wilderness and Research Natural Area
ELEVATION

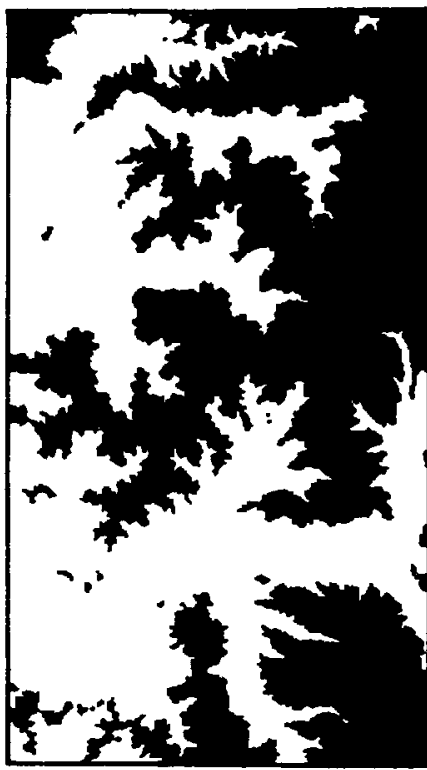

Low Elevation $(<914 m)$

High Elevation $(>014 m)$

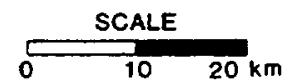

Fig. 1. The study area in western Oregon showing distributions of major ownerships and land allocations and elevation zones.

1985, Schoonmaker and McKee 1988, Ruggeiro et al. 1991).

\section{METHODS}

Raw digital satellite data sets for 1972, 1976, 1981, 1984, and 1988 were selected from Landsat MultiSpectral Scanner (MSS) scenes and rectified using orthophoto quadrangles to a universal transverse mercator projection. Additional information on the characteristics of Landsat MSS data can be found in Lillesand and Kiefer (1987). To minimize vegetation differences from seasonal changes, all of the MSS image data used in the study were from the three summer months. The Earth Resources Data Analysis System (ERDAS) was used to implement a nearest neighbor interpolation method with resampling at $50 \times 50 \mathrm{~m}$ pixel size from the original $57 \times 79 \mathrm{~m}$ pixel size.

After rectification, each image was classified into three broad cover types: closed canopy conifer forest (CF), other forest and nonforest types (OT), and water. Closed-canopy conifer forests, i.e., stands in which conifer crowns occupied at least $60 \%$ of the area, ranged in age from 40 to $750 \mathrm{yr}$, and were typically at least $15-30 \mathrm{~m}$ tall. The OT class included recent clearcuts, brush fields, young pre-canopy-closure conifer plantations, and closed-canopy stands dominated by de- ciduous trees. Pixels classed as water consisted primarily of large reservoirs.

Only two forest cover classes were used to simplify the change analysis, to emphasize cutting patterns, and to minimize the ground-truthing needed to develop the classification. Our purpose was to quantify rates of disturbance and changes in spatial pattern relative to the initial matrix of conifer forest. Consequently, we did not distinguish among different classes of closedcanopy conifer forest including old-growth, or different classes of early successional and deciduous cover. Although this simplification may limit the relevance of our results for old-growth issues, the ecosystem transitions represented by the two classes encompass the two most dramatic changes in biological diversity and ecosystem function that occur in these landscapes: (1) the change from a natural conifer forest to an early successional clearcut, and (2) the change from an open or deciduous ecosystem to a conifer-dominated ecosystem.

We used an unsupervised classification scheme in which the image data were aggregated into 100-150 natural spectral classes, then grouped into the three classes described above (Lillesand and Keifer 1987). The accuracy of the 1972 and 1988 image classifications was assessed using aerial photography. A system- 
TABLE 1. Area of closed-canopy coniferous forest (CF) and other forest and nonforest types (OT) in 1972 and 1988 and net change in CF by ownership and allocation.*

\begin{tabular}{|c|c|c|c|c|c|c|c|c|c|c|}
\hline \multirow{3}{*}{$\begin{array}{l}\text { Land ownership } \\
\text { and allocation }\end{array}$} & \multicolumn{4}{|c|}{ Amount in 1972} & \multicolumn{4}{|c|}{ Amount in 1988} & \multirow{2}{*}{\multicolumn{2}{|c|}{ Net change in $C F$}} \\
\hline & \multicolumn{2}{|c|}{$\mathrm{CF}$} & \multicolumn{2}{|c|}{ OT } & \multicolumn{2}{|c|}{$\mathrm{CF}$} & \multicolumn{2}{|c|}{ OT } & & \\
\hline & ha & $\%$ & ha & $\%$ & ha & $\%$ & ha & $\%$ & ha & $\%$ \\
\hline $\begin{array}{l}\text { Wilderness } \\
\text { Public nonwilderness } \\
\text { Private } \\
\text { Entire area }\end{array}$ & $\begin{array}{r}18571 \\
125785 \\
39493 \\
183849\end{array}$ & $\begin{array}{l}93.4 \\
78.6 \\
50.0 \\
71.0\end{array}$ & $\begin{array}{r}1307 \\
33881 \\
38677 \\
73865\end{array}$ & $\begin{array}{r}6.6 \\
21.2 \\
49.0 \\
28.5\end{array}$ & $\begin{array}{r}18374 \\
109500 \\
21777 \\
149651\end{array}$ & $\begin{array}{l}92.4 \\
68.4 \\
27.6 \\
57.8\end{array}$ & $\begin{array}{r}1504 \\
50094 \\
56369 \\
107967\end{array}$ & $\begin{array}{r}7.6 \\
31.3 \\
71.0 \\
41.7\end{array}$ & $\begin{array}{r}-197 \\
-16285 \\
-17716 \\
-34198\end{array}$ & $\begin{array}{r}-1.1 \\
-12.9 \\
-44.9 \\
-18.6\end{array}$ \\
\hline
\end{tabular}

* Percentages may not sum to 100 because area of water is not included.

atic sampling of 135 points was applied across the study area. High-altitude color-infrared photographs were used to check each point for correctness of classification. Limited reconnaissance on the ground and previously established vegetation plots (Spies and Franklin 1991) were also used to verify classification success.

The classification of cover types was overlaid with the spatial variables of land ownership and elevation using ERDAS. Wilderness, Research Natural Areas, and State Parks were put in a separate public ownership class because they will remain uncut. Elevation was divided into two classes; $>914 \mathrm{~m}$ (3000 feet) above MSL and $\leq 914 \mathrm{~m}$. The $914-\mathrm{m}$ elevation approximates the division between the Western Hemlock and Pacific Silver Fir Zones (Franklin and Dyrness 1973), and it is a transition where many warm climate vertebrate species do not occur and many cool climate vertebrate species begin to occur (Harris 1984).

Maps of forest edge and interior were constructed from the classified Landsat maps by using a geographic information system (GIS). Edge length was defined as the total linear distance along the closed-canopy forest boundary, and the percentage of edge was defined as the percentage of pixels with edge of the total pixels. Interior habitat was defined as the amount of closedcanopy forest remaining after designating a $100-\mathrm{m}$ edge zone. The width of the edge zone was based on a study of high-contrast edges ( $50-60 \mathrm{~m}$ tall conifer forests that border recent clearcuts) in which edge effects as measured by microclimate and vegetation dynamics extended from 20 to at least $240 \mathrm{~m}$ into the forest, depending on the variable examined (Chen 1991). A $100-\mathrm{m}$ edge zone was applied because many edge effects are considerably reduced by this distance, and edges in the study area are lower contrast than are edges between a clearcut and old-growth edge and presumably have narrower zones of edge effect than the maximum.

Three analyses of subsamples $(5000 \times 5000 \mathrm{~m}$ or $2500 \mathrm{ha}$ ) of private and public nonreserve forest land were conducted to provide a more controlled comparison of the differences in development of landscape pattern between the two types of forest ownerships. In the first analysis, the changes in forest patterns from early to later stages of logging entry were examined in a single subsample with a high percentage of $\mathrm{CF}$ in
1972 and relatively high rates of cutting. This subsample was subjectively chosen from each ownership and compared over the five dates. In the second analysis, relations of area cutover to edge and interior habitat were compared. Six subsamples were subjectively chosen to obtain a wide range of percentage CF for each ownership from either the 1972 or 1988 classification, and then the percentage of edge and percentage of interior habitat were plotted against the percentage CF. In the third subsampling analysis, within-ownership variability (coefficient of variation) in cutting rates was estimated and compared from a random selection of six subsamples from each ownership for which changes in CF between 1972 and 1988 had been calculated.

\section{RESULTS \\ Accuracy of classification}

Classification accuracy was estimated to be $\approx 91 \%$ for both the 1972 and 1988 scenes. In 1972, 91\% of the closed-canopy conifer forest and $92 \%$ of the other cover types were correctly classified. In $1988,89 \%$ of the closed-canopy conifer forest and $94 \%$ for the other cover types were correctly classified. The overall accuracy of change statistics between 1972 and 1988 was $83 \%$, using a simple joint probability assuming a uniform distribution of error throughout the maps.

\section{Forest cover}

The percentage of closed-canopy conifer forest (CF) in the entire landscape declined from $71.0 \%$ in 1972 to $57.8 \%$ in 1988 , equivalent to a decline of $\approx 34000$ ha (Table 1). Amounts and changes in the proportions of the two forest types differed strongly by land ownership and allocation (Table 1 and Fig. 2). The highest percentage of $C F$ and least amount of change in percentage of CF between 1972 and 1988 (93.4 to $92.4 \%$ ) occurred on public wilderness and reserve lands, and the lowest percentage of $\mathrm{CF}$ and the greatest decline in percentage of CF (50.0 to $27.6 \%$ ) occurred on private forest lands. Public nonwilderness was intermediate to the other ownerships and allocations in percentage of CF and decline in percentage CF between 1972 and 1988 (78.6 to $68.4 \%)$.

Change in closed-canopy conifer forest was roughly linear during the $16 \mathrm{yr}$ for both ownerships (Fig. 3b). The greatest 4-yr declines in forest cover occurred be- 
1972

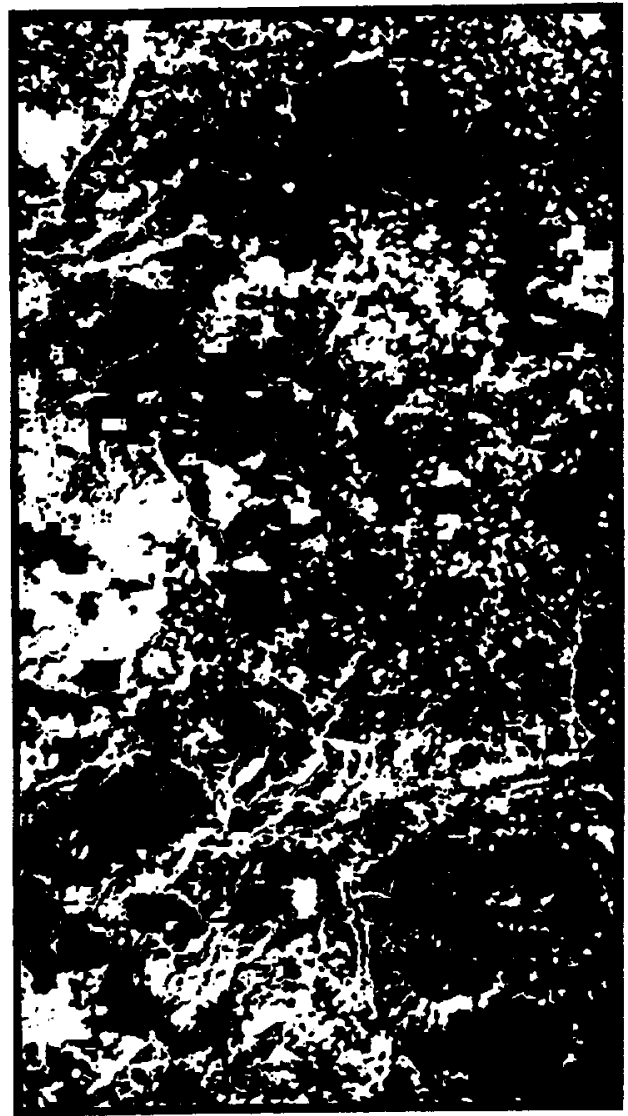

CENTRAL CASCADE MOUNTAINS

\section{LEGEND \\ Conifer Type}

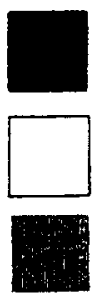

Other Types
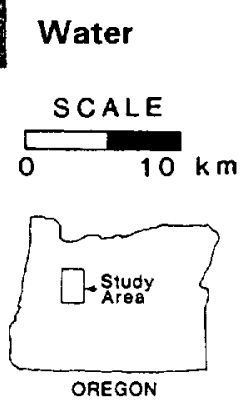

1
1988

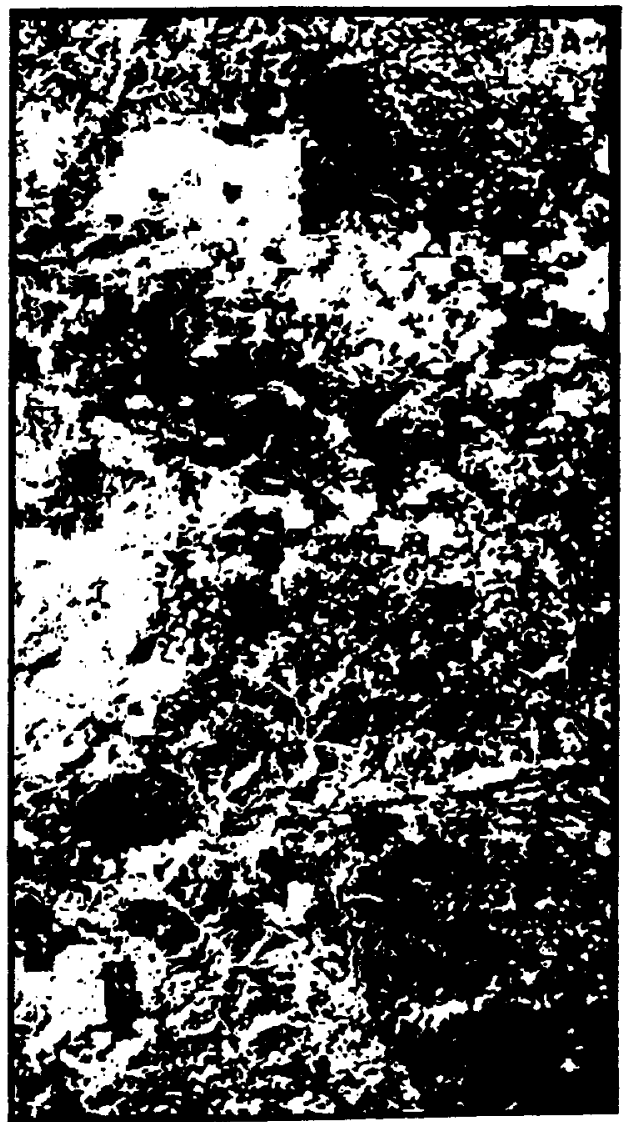

Fig. 2. Distribution of the conifer type and other types in the study area in 1972 and 1988.

tween 1984 and 1988 on public lands and between 1981 and 1984 on private lands. The pattern of change was similar at low and high elevations, although the low elevation sites had a lower percentage of closed canopy forest during the entire period (Fig. 3a).

\section{Transitions between forest cover types}

Pixels of CF in 1972 that became other forest and nonforest types (OT) by 1988 represent disturbances, primarily clear-cutting, that created early successional forests. Transitions in the other direction, pixels of OT in 1972 that became CF by 1988 , represent succession and stand development. During this period the disturbance-caused transition rate between forest types was greater than the succession-caused transition rate between forest types. Over the entire area, the percentage of CF in 1972 that changed to OF by 1988 was 26.8 , whereas the percentage of OT in 1972 that changed to CF by 1988 was 20.5 (Table 2). This trend was very strong on private lands, where disturbance transition rates were over three times greater than successional transition rates (Table 2). On public lands, the pattern was opposite to that of private lands: successional transition rates were slightly higher than disturbance transition rates on nonreserve lands and they were $\approx 10$ times higher on reserve lands.

\section{Disturbance rates and rotations}

The annual rate of disturbance (based on area disturbed between 1972 and 1988 as a percentage of the total study area) and corresponding rotation age (inverse of the annual percentage of cutting rate) for the entire study area including wilderness was $1.19 \%$ and $84 \mathrm{yr}$. The annual rates of cutting on public nonwilderness land and private lands were 0.95 and $2.14 \%$. These rates translate into forest rotations of 105 and $47 \mathrm{yr}$.

\section{Changes in edge and interior habitat}

Edge habitat. - The percentage of edge increased slowly over the 16-yr period (Fig. 3c, d). The density of edge increased from 1.9 to $2.5 \mathrm{~km} / \mathrm{km}^{2}$. The greatest increase in edge occurred between 1984 and 1988 (Fig. 3). Low elevations had higher proportions of edge than did high elevations (Fig. 3). The proportion of edge was lower on public lands than on private lands until 1988 , when the proportion of edge on public lands increased rapidly to nearly the same proportion as on private lands (Fig. 3d).

Interior habitat. - The amounts and percentages of interior CF steadily declined during the study period (Fig. 3). High elevations had a consistently greater percentage of interior forest than did low elevations (Fig. 

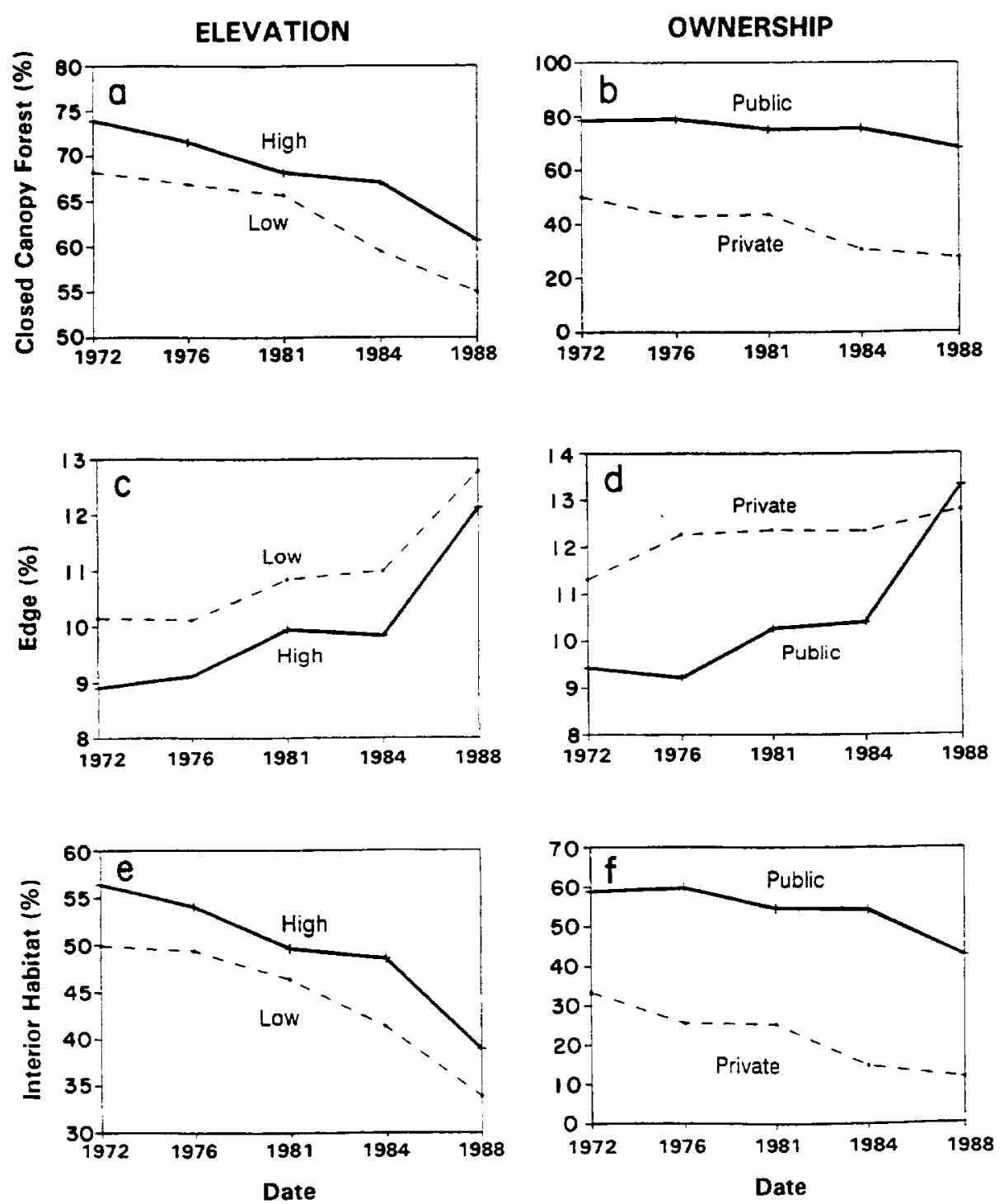

FIG. 3. Percentage of study area in conifer forest (a-b), edge ( $c-d)$, and interior habitat for five dates between 1972 and 1988, by elevation (a, c, and $e$ ) and ownership (b, d, and f)

3e). Private lands had much less interior forest than did public lands throughout the study period (Fig. 3f). By 1988 , only $\approx 12 \%$ of the private lands were covered by interior forest, whereas public lands were $\approx 43 \%$ interior forest.

Interior habitat patch area. - Between 1972 and 1988, forest interior patches became smaller and more numerous (Fig. 4). Mean interior patch area declined from 160 to $62 \mathrm{ha}$. In addition, the percentage of interior forest area in large patches decreased (Fig. 4). In 1972, $50 \%$ of the total study area was in connected concentrations of interior habitat of at least 1000 ha; by 1988 , the total had declined to $26 \%$. During the $16 \mathrm{yr}$, a very large patch of 103608 ha was broken into several smaller aggregates of $<25000$ ha, concentrated primarily on public lands (Fig. 5).

Large patches were all on public lands and concen- trated around: Three Sisters Wilderness (21018 ha), Santiam River corridor (17009 ha), Santiam Wilderness Area (14774 ha), H. J. Andrews Experimental Forest (6139 ha), and Hagan Research Natural Area (4097 ha) (Fig. 5). Although these large patches all consisted of connected interior forest, they varied considerably in the amount and pattern of OF and noninterior CF contained within them. For example, the Three Sisters Wilderness in the southeast corner had relatively large aggregations ( $3000-5000 \mathrm{ha})$ of interior forest; the Santiam River corridor consisted of smaller, long, narrow interior forest aggregations and noninterior forest area $(<2000 \mathrm{ha})$. In 1972, the study area was still dominated by interior forest habitat; by 1988 , interior forest habitat was the dominant landscape condition only in subareas associated with special forest land allocations. 


\section{Landscape subsample analyses}

Progression of cutting and regrowth. - Cutting patterns developed differently on public and private subareas (Fig. 6). On the private land subsample, where CF declined from 92 to $10 \%$, large cut units in the upper and left portions of the block in 1972 became the foci of the very large cutover areas that appeared in 1981-1988. By 1988, the private subsample was characterized by isolated blocks of CF ranging from a few to $\approx 70$ ha. On the public land subsample, where the percentage of CF declined from 84 to $65 \%$, a dispersed pattern of small cuts in 1972 in the upper right expanded slowly in subsequent years by the dispersal of small units into the large uncut block in the lower portion of the area (Fig. 6). This large block remained relatively uncut until 1984 . During this same period, cutting also occurred around the older units in the upper right portion of the image, resulting in aggregation of cutover areas. Until 1984, the conifer forest was entirely a connected matrix. During 1984 and 1988 , a few small ( $<10$-ha) isolated forest blocks began to appear in the area in which cutting initially began (Fig. 6).

Because of the occurrence of older plantations and large cutover areas, regrowth of CF was more easily illustrated on private lands than on public lands, where plantations were younger and regrowth was dispersed in relatively small units over large areas. Regrowth of CF for a subsample of private land followed a spatial process of nucleation, in which relatively large areas of CF in $1988(53.9 \% \mathrm{CF})$ regrew from smaller foci of CF in 1972 (33.9\% CF) (Fig. 7). Patterns of regrowth were only illustrated for 1972 and 1988 because the changes at 4-yr intervals were so small that they tended

TABLE 2. Transitions in forest conditions between 1972 and 1988 , based on areas in forest condition in 1972 (see Table 1) by owernship and allocation.

\begin{tabular}{lcc}
\hline \hline & \multicolumn{2}{c}{ Type of change } \\
\cline { 2 - 3 } \multicolumn{1}{c}{$\begin{array}{c}\text { Land ownership } \\
\text { and allocation }\end{array}$} & $\begin{array}{c}\text { Disturbance } \\
\text { (CF to OT) }\end{array}$ & $\begin{array}{c}\text { Succession } \\
\text { (OT to CF) }\end{array}$ \\
\hline & \multicolumn{2}{c}{ Changes in hectares } \\
\cline { 2 - 3 } Wilderness & 655 & 459 \\
Public nonwilderness & 24210 & 8001 \\
Private & 24396 & 6702 \\
Entire area & 49261 & 15162 \\
& \multicolumn{2}{c}{ Changes in percentages } \\
Wilderness & 3.5 & 35.1 \\
Public nonwilderness & 19.2 & 23.6 \\
Private & 61.8 & 17.3 \\
Entire area & 26.8 & 20.5 \\
& Mean annual rates \\
& of change (\%/yr) \\
Wilderness & 0.2 & 2.2 \\
Public nonwilderness & 1.2 & 1.5 \\
Private & 3.9 & 1.1 \\
Entire area & 1.7 & 1.3 \\
\hline
\end{tabular}
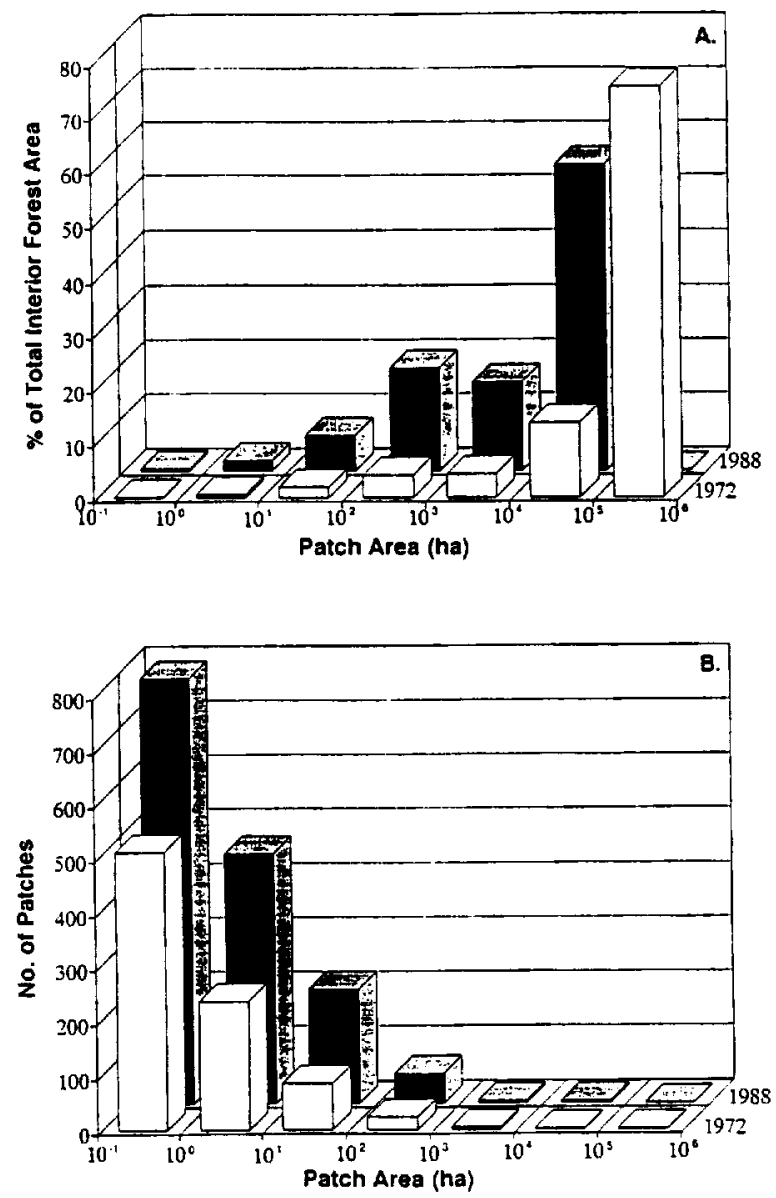

Fig. 4. Distribution of interior forest patch sizes in 1972 and 1988 in relation to percentage of total interior forest (A) area and total number of patches (B).

to be obscured by differences among the classifications of OT and CF for each date. The change from OT to CF from succession was much more gradual and less contrasting than the sudden change from CF to OT caused by clear-cutting.

Interior and edge. - Public land subsamples had less interior habitat and more edge habitat than private land blocks over a comparable range of cutover percentages (Fig. 8A). On public lands the percentage of edge rose to a peak at $\approx \mathbf{4 0} \%$ cutover and then declined, roughly following a pattern predicted by Franklin and Forman (1987) for a uniform checkerboard model of cutting patterns. The private lands subsamples exhibited less edge per percentage of cutover and showed a relatively flat relation between edge and percentage cutover. The private land was probably cut in different types of patterns that created a relation of edge to cutover area that is a mixture of several spatial cutting models. Aggregated cutting after the landscape was $40 \%$ cutover resulted in a decline in percentage of edge for both ownerships, although the amount of edge after the $40 \%$ point varied considerably (Fig. $8 B$ ). 


\section{INTERIOR FOREST PATCHES}

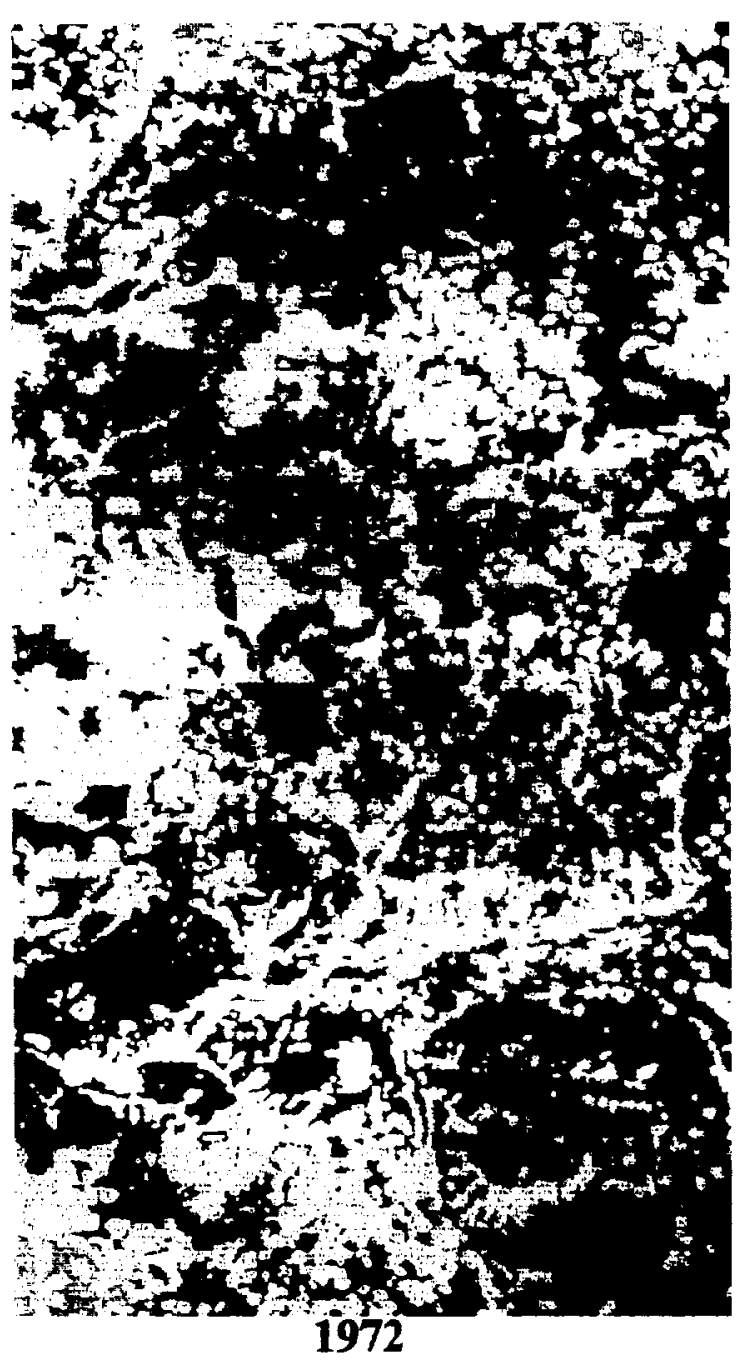

\section{LEGEND}

$\begin{array}{ll}1972 & 1988 \\ \text { Patch Size } & \text { Patch Size } \\ <1000 \mathrm{he} & <1000 \mathrm{ha} \\ 3383 \mathrm{ha} \\ 1149 \mathrm{hg} & 4097 \mathrm{ha} \\ 1622 \mathrm{ha} & 6136 \mathrm{ha} \\ 3188 \mathrm{ba} & 14774 \mathrm{ha} \\ 18700 \mathrm{hg} & 17009 \mathrm{ha} \\ 103608 \mathrm{ha} & 21018 \mathrm{ha}\end{array}$
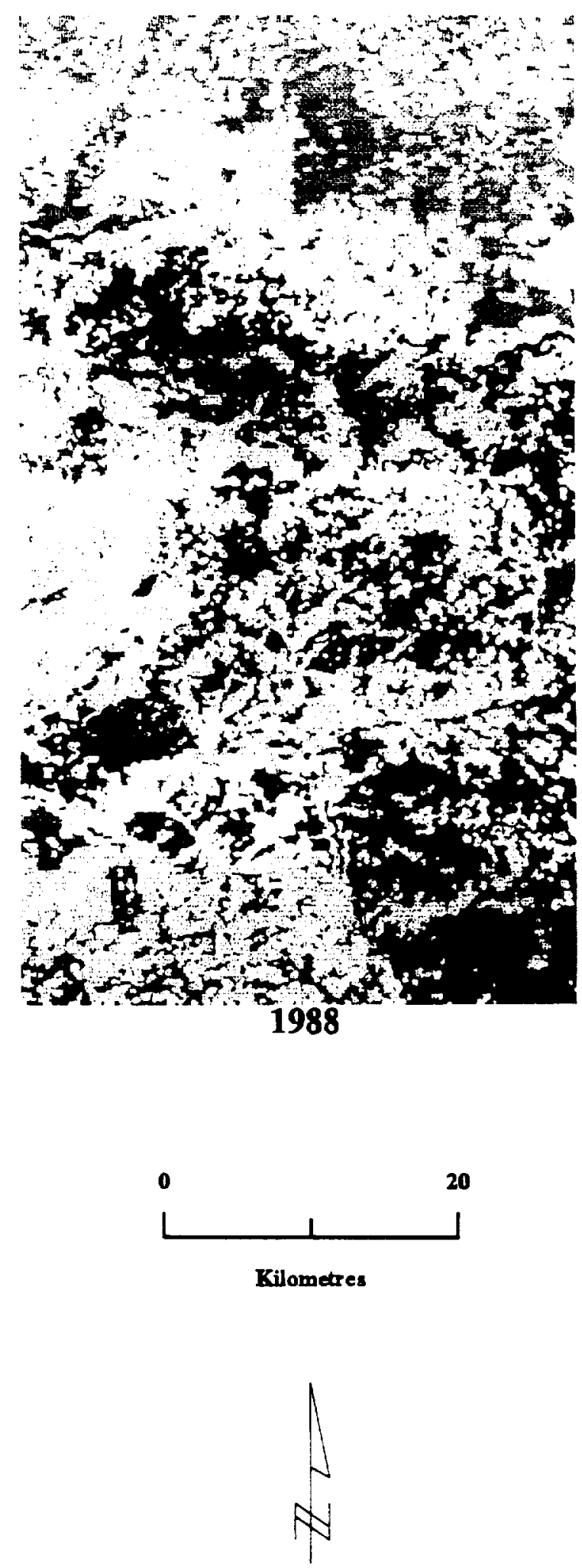

Fig. 5. Pattern of connected interior conifer forest patches in 1972 and 1988 . Patches larger than 1000 ha are shown in different colors. 
Private
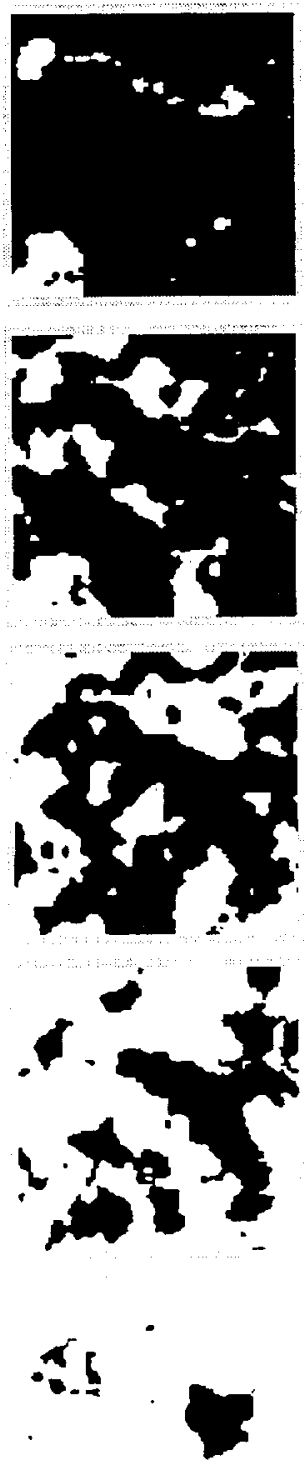

1988

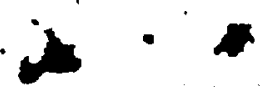

1976

1981

1984

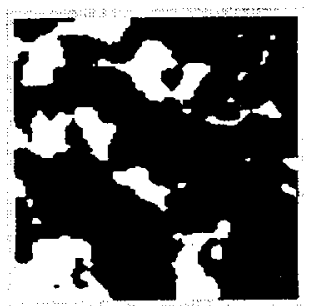

Public
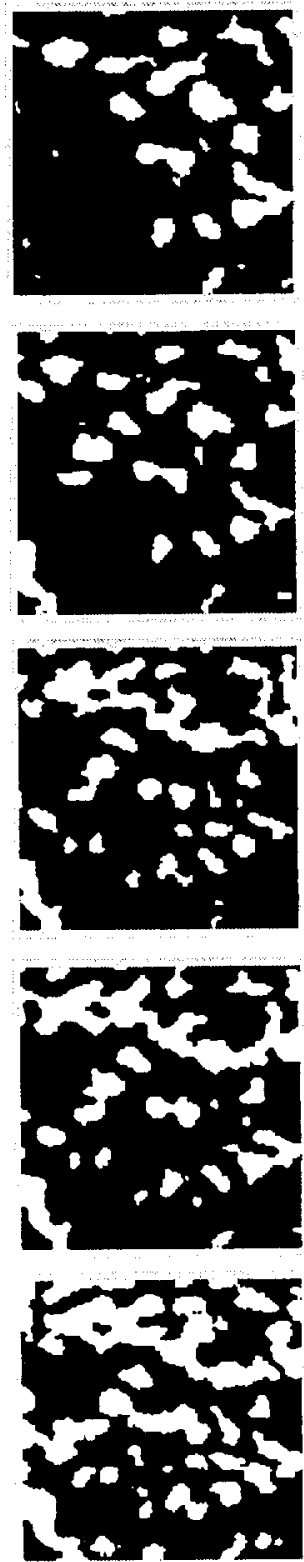

FIG. 6. Changes in conifer type ( $\square$ ) and other types ( $\square$ ) for a private and public sublandscape ( $2500 \mathrm{ha}$ ) with similar initial conditions and rates of change that are relatively high for the ownership type.

Variability in cutting rates. - Variability in rates of change of CF among subsamples from the private lands was greater than among subsamples from the public nonwilderness lands. The coefficient of variation of change in proportion of CF in the landscape, based on six 2500 -ha subsamples, was $198 \%$ for private lands and $48 \%$ for public nonwilderness. The range of change in percentage of $C F$ in a subsample was -4.5 to $-14.5 \%$ for public nonwilderness and $+14.7 \%$ to $-82.5 \%$ for private lands. The differences reflect the application of dispersed cutting practices within the public ownership and the more aggregated cutting practices of private forest owners.

\section{Discussion \\ Comparison with ground-based estimates of change}

The rates of cutting and regrowth of conifer forest that we estimated from satellite imagery were generally compatible with estimates based on ground-based inventories and forest management plans. Commercial forest land on the Willamette National Forest was cut at a rate of $0.9 \%$ from 1972 to 1988 (J. Mayo, personal communication), which is nearly identical to our estimate. The planned dominant harvest rate as of 1990 was $1.2 \%$ per year ( 80 yr rotation) (Anonymous 1990 ).

For all private forest lands in two regions in central western Oregon, an area of $>4600 \mathrm{~km}^{2}$, cutting rates averaged $\approx 1.0 \%$ between 1975 and 1985 (Greber et al. 1990), which is considerably lower than our estimate of $2.1 \%$. We probably observed locally high rates of cutting on this portion of private land. However, many industrial and nonindustrial private lands are now using cutting rates of $\approx 1.8 \%$ per year or rotations of $55 \mathrm{yr}$ (Greber et al. 1990:40), which is closer to the rate we found. A few industrial owners are using or planning rotations as short as 25 yr for Douglas-fir (K. N. Johnson, personal communication).

\section{Transition rates and condition of the steady-state landscape}

The high rate of disturbance (clear-cutting) on private lands is a consequence of management objectives weighted to maximize short-term financial return. The lower rate of successional transition on private land (1.1\%) compared to public land $(1.5 \%)$ probably is a consequence of some private cut units changing to deciduous forest types, such as red alder and bigleaf maple, or staying longer in low-density conifer/shrub stands. These deciduous forest types would eventually succeed to closed canopy conifer-dominated types or sometimes stay in semipermanent, open, conifer-shrub types. Forest management practices on some private

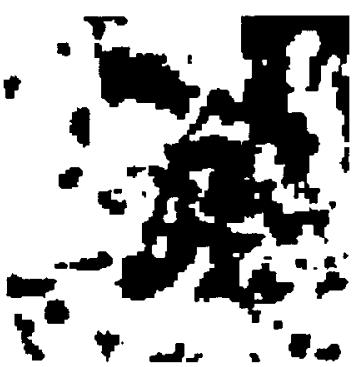

1972

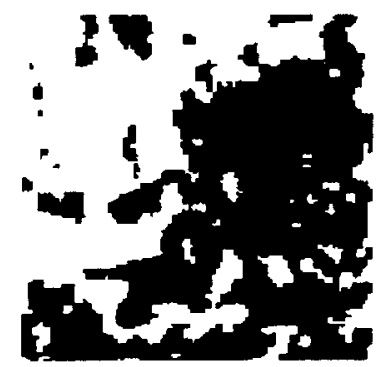

1988
Fig. 7. Example of patterns of regrowth and cutting of closed-canopy conifer forest $(\square)$ on private land between 1972 and 1988. 

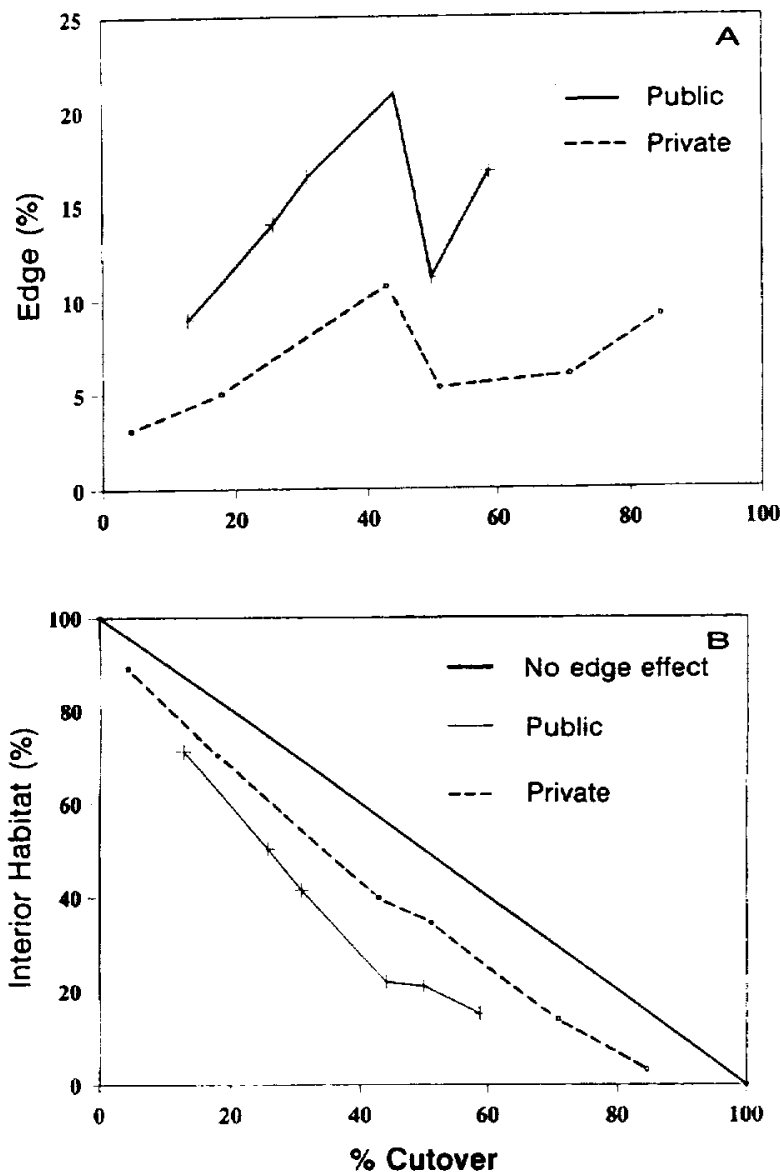

FIG. 8. Relation between percentage of cutover and percentage of interior habitat (A) and percentage of edge (B) for six public and six private sublandscapes $(2500 \mathrm{ha})$ from either 1972 or 1988 conditions.

lands in the 1950 s and 1960 s resulted in sparse conifer regeneration and dense regeneration of red alder, which can outcompete conifers on some sites. Conifer regeneration failures on private lands led to passage of the Oregon Forestry Practices Act in 1971, which requires land owners to replant lands to commercial tree species within 2 yr. Recent regeneration practices have resulted in shortening the time between clear-cutting and the development of well-stocked plantations of merchantable conifers on most private lands. Sparsely regenerated conifer plantations represent $<5 \%$ of the industrial private land but as much as $30 \%$ of the nonindustrial private lands of central western Oregon (Greber et al. 1990, J. Ohmann, personal communication).

This forest landscape is not in steady state (unchanging proportions of forest types) or in a regulated forest condition (i.e., equal proportions of all age classes). A regulated forest condition is not projected for $\approx 40 \mathrm{yr}$, based on current age-class distributions and assuming a 100-yr rotation on public land, a 55-yr rotation on private lands, and canopy closure at 40 yr (Fig. 9). The proportion of landscape in CF in a regulated forest condition will depend on the rotation length and the age at which canopy closure occurs. If public lands were to use a $200-y r$ rotation, then $80 \%$ of the landscape would be $>40$ yr (Fig. 9). If canopy closure were accelerated on private lands and occurred at $30 \mathrm{yr}$, which is already the case on many private lands, then $40 \%$ of that ownership would be in CF (Fig. 9). However, given the likelihood of natural disturbances and future changes in policy, the manager's ideal of a fully regulated forest will probably remain a theoretical target.

\section{Comparison with natural disturbance regimes}

The natural disturbance regime of the study area is characterized by both fine-scale ( $<1$ ha) and coarsescale ( $>1$ ha) disturbances (Spies and Franklin 1988). In this study we focused primarily on coarse-scale disturbances that historically were fires. The natural fire regime of the study area is incompletely understood, but it appears to be complex in terms of frequency, intensity, and patch sizes. In a study of the fire history from 1150 to $1900 \mathrm{AD}$ of two 1940-ha landscapes within our study area, Morrison and Swanson (1990) estimated natural fire rotations of 150 and $276 \mathrm{yr}$ for moderate- to high-intensity fires. Some sites burned every $20 \mathrm{yr}$, while others burned only once in $400 \mathrm{yr}$. Fire patches were irregular in shape and intensity, with most fires killing only a portion of the trees within a patch. Patch sizes were highly variable but were typically $<10$ ha.

In contrast, the management disturbance regime we observed is several times more frequent and much more severe in terms of live trees and coarse woody debris

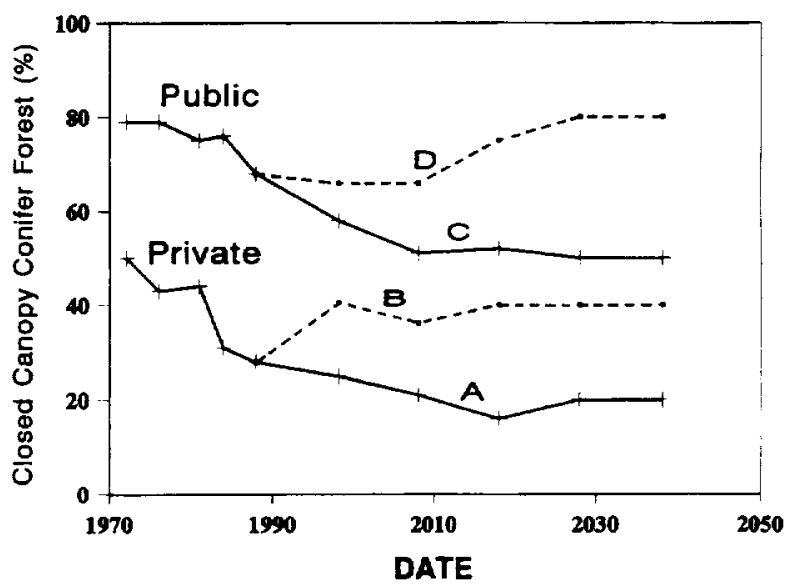

Frg. 9. Past and future projected changes in the proportion of study area covered by closed canopy conifer forest ( $>40$ yr) by ownership. The projections assume a 55-yr rotation on private land (A) and a 100-yr rotation on public land (C). Alternative future proportions of closed-canopy forest include a 200-yr rotation age (D), and closed-canopy conditions $o c$ curring at $30 \mathrm{yr}$ (B). The data from 1972-1988 are from this study and the projections are based on Greber et al. (1990) for private lands and the Willamette Forest Plan (Anonymous 1990) for public lands. 
left following the disturbance (Spies and Cline 1988). Clearcut patch sizes appear to be similar to the typical fire patch size; however, the distribution of clearcut patch sizes is probably narrower, lacking disturbance patch sizes $>100$ ha. However, the higher frequency of clear-cutting cumulatively creates large patches of early successional conditions in a relatively short period of time.

The high disturbance rates create a higher proportion of the landscape in an early successional state than on average during the last several hundred years. This results in increases in populations of early successional species at a landscape scale and an increased density of seed rain and establishment of those species in disturbance patches. While these species are not likely to invade the areas of closed-canopy forests, through mass effects they may become more common in natural disturbances such as treefalls and wildfires that occur within natural forest areas. Also, contact zones or edges between early successional deciduous forests and closedcanopy coniferous forests will be more common, resulting in increased edge effects from microclimatic change (Chen 1991) and predation and competition. Finally, the short return intervals between major disturbances will not allow late successional ecosystems to develop and species and processes dependent on longer intervals will be lost on sites where cutting occurs at short intervals.

\section{Comparison with other landscape change studies}

Comparable studies of forest landscape change have been done in the tropical forest areas where cutting rates range from $<0.5 \%$ (Nelson et al. 1987) to $1.7 \%$ (Fernside 1982: Table III) to $>7.7 \% / \mathrm{yr}$ (Sader and Joyce 1988). In many of these tropical landscapes, however, the deforestation is a result of agricultural expansion, whereas in Northwest temperate conifer forests, the change is typically from one forest condition to another. The loss of mature and old-growth forest habitat in the study area during this period, however, was at least semipermanent because current rotations and practices do not allow for redevelopment of this forest type.

The landscape dynamics we observed differed in several respects from the dynamics of the Superior National Forest in northern Minnesota between 1973 and 1983 (Hall et al. 1991). In the Minnesota landscape, the percentage of nonwilderness in mid- to late-successional "mixed and conifer states" increased at an annual rate of $0.2 \%$ (55 to $57 \%$ ) between 1973 and 1983; on nonwilderness public lands in Oregon, the percentage of the mid- to late-successional conifer type decreased at an annual rate of $0.7 \%$ (79 to $68 \%$ ) between 1972 and 1988. Stability of individual mid- to late-successional patches, however, appeared to be lower in Minnesota than in Oregon; 54 and $51 \%$ of the mixed and conifer types in Minnesota remained or returned to those types during the $10 \mathrm{yr}$, but in Oregon, $81 \%$ of the conifer type was still in that condition after $16 \mathrm{yr}$.
The annual rates of major disturbance (change to "Clearings," "Regenerating," or "Broadleaf" types in the Minnesota study) in the mixed and conifer types on nonwilderness lands in Minnesota were 2.7 and $1.8 \%$, but in Oregon the annual disturbance rate to the conifer type was $1.2 \%$. Wilderness lands in both areas experienced lower disturbance rates than the nonwilderness lands; however, the Minnesota wilderness experienced higher disturbance rates than did the Oregon wilderness ( 0.7 vs. $0.2 \%$ for the conifer types).

\section{Comparison with the checkerboard model}

Although the relations of edge and interior habitat to percentage cutover in the public, nonwilderness landscapes generally supported the simple checkerboard model of Franklin and Forman (1987), their model clearly could not account for all of the complexity of landscape pattern and dynamics in a real landscape. On National Forest lands, the dispersedcutting system did not result in a uniformly dispersed pattern at all scales, as the model assumed. For example, large-scale aggregations of 3000-20000 ha of interior forest were still present in 1988. These interior forest aggregates, although they are not continuous uncut forest blocks, do retain a matrix that may provide adequate amounts and connectivity of habitat for relatively mobile organisms, such as the Spotted Owl (D. Johnson, personal communication), that can stay within the matrix of connected mid- to late-successional conifer forest, or cross short distances of young forest plantations.

The Franklin-Forman model did not include forest stand regrowth, which means that the highly cutover states simulated in the checkerboard model are never reached in a real landscape, at least for areas larger than several hundred hectares. In addition, regrowth of young stands reduces the distance that edge effects occur in adjacent taller stands and lessen the negative effects of cutting for processes and species that return to predisturbance conditions when the conifer canopy closes. On public lands where the predominant rotation is currently planned at $80 \mathrm{yr}$, the maximum area in canopy closure (assuming closure by $40 \mathrm{yr}$ ) would be $\approx 50 \%$ (Fig. 8). Based on this study and the simulations of Franklin and Forman (1987), a landscape with 50\% cut in a staggered setting pattern would be close to or past the maximum percentage of edge in the landscape.

Franklin and Forman (1987) predicted landscape pattern thresholds at 30,50 , and $70 \%$ cutover for the dispersed patch cutting model. The $30 \%$ threshold was the point at which average forest patch size starts to decline because the original forest patch is so perforated that it begins to fragment into separate patches. Lehmkuhl et al. (1991), however, argue that the actual area of the forest patch that is available as habitat decreases linearly between 0 and $30 \%$, as habitat within the patch is changed through cuts in the forest matrix. Consequently, decline in patch area begins with the 
first cut, and the $30 \%$ threshold from the checkerboard model may be more geometric than ecological, although what effect the occurrence of the first few breaks in the original matrix have on organism dispersal is not clear. The $50 \%$ cutover threshold-the point of maximum edge density (length of edge per unit area) in the landscape and point of increase in cutover patch size-we observed at $40 \%$ cutover in our subsamples. The $70 \%$ cutover threshold-the point at which the landscape becomes one contiguous cutover patch - was not observed at the scale of our subsampling. Because of the nonuniform application of the staggered-cutting model in the actual landscape, thresholds in patterns do not occur exactly where the checkerboard model would predict, or they do not occur at all. Furthermore, the occurrence of pattem and function thresholds will be scale dependent (Grant 1990). Small areas may be cut-over relatively rapidly, but, at a larger scale, they may be part of larger, relatively uncut aggregates. This scale-dependent pattern in the actual implementation of the staggered setting system means that effects of cutting patterns on hydrology or wildlife dispersal must be examined across a range of landscape sizes.

\section{Influence of cutting rate on landscape pattern}

The influence of cutting pattern on the amount of edge and interior forest has been documented by Franklin and Forman (1987) and is supported by the results of the ownership comparison in this study (Fig. 8 ). The influence of cutting rate on amount of edge and interior forest, however, has not been addressed in other studies, and the results of this study suggest that cutting rate can have a greater effect on the amount of edge and interior forest in a landscape than cutting pattern. For similar rates of cutover in the subareas, private land had more interior habitat and less edge habitat than public nonwilderness land, which would be expected because private lands tend to use larger clearcuts than public lands and are not constrained by dispersion rules. However, when the two landscapes as a whole were compared, the private land had much less interior forest and much more edge (at least for 1972-1984) than the public land. This difference results from the fact that cutting on private land has progressed further and more rapidly than it has on public lands. While it is obvious that higher rates of cutting result in lower amounts of interior habitat, discussions of alternative landscape management approaches in the region have typically focused on the effects of alternative cutting patterns on habitat (Franklin and Forman 1987, Swanson and Franklin 1992). While altering cutting patterns rather than rotations may be more economically viable, lengthening timber rotations will provide greater areas of older forest and interior habitat.

\section{Stages of landscape pattern dynamics}

Fragmentation is only one stage of landscape pattern dynamics that result from the simultaneous operation of disturbance and regrowth. If the rate of disturbance exceeds the rate of regrowth, large forest areas will become increasingly perforated with disturbance and early successional patches. In this perforation stage, gaps occur in the forest matrix but the forest remains connected. Continued relatively high rates of disturbance will lead to a fragmentation stage in which the perforated habitat is broken into isolated patches. A third stage of pattern dynamics occurs when the last remnant habitat patches are lost through disturbance. The spatial process of forest habitat redevelopment occurs in an inverse manner. First, small nuclei of forest habitat reappear as small, widely separated patches in the landscape. This process of nucleation is followed by a stage of coalescence in which the smaller nuclei expand and coalesce into large patches that eventually can completely cover the area, if disturbance rates are low. Because disturbance and regrowth operate at the same time in a landscape, the stages described above do not necessarily occur in sequence.

The study area is in the perforation to early fragmentation stages of landscape dynamics. At this point in landscape development, community responses are probably characterized by increases in species richness, as early successional species increase, but coniferous forest species and interior species may still find adequate habitat. Increases in bird species diversity have been observed in Douglas-fir stands 40-500+ yr old as the percentage of clearcuts in the landscape increased from 0 to $50 \%$ (Lehmkuhl et al. 1991). In the early stages of cutting, relatively mobile organisms whose habitat is lost may move to adjacent areas of suitable habitat, resulting in a packing effect (Whitcomb et al. 1981). Lehmkuhl et al. (1991) have observed increased bird abundances in old-growth Douglas-fir stands in landscapes with higher percentages of clearcuts than in landscapes with low percentages of clearcuts. The early stages of cutting may also be characterized by increases in the occurrence of mobile early-successional grazers, predators, and competitors within the forest matrix. For example, Great Horned Owls (Bubo virginianus) in the Pacific Northwest, which prefer relatively open habitat and forest edges for hunting (Forsman et al. 1984, Voous 1989), may increase predation on interior forest species that occur near edges or move across open areas within the forest matrix. Barred Owls (Strix varia), which may compete (Hamer 1988) or hybridize with Spotted Owls, are more tolerant than Spotted Owls of landscapes composed of a mix of early- and latesuccessional habitats (Taylor and Forsman 1976). The recent expansions in Barred Owl populations in the Pacific Northwest (Taylor and Forsman 1976) may be facilitated by the increased juxtaposition of early- and late-successional habitats. 


\section{Management implications}

We have presented a simplified landscape analysis that emphasizes rates and patterns of cutting and closedcanopy forest. Our analysis is too simplified for comprehensive ecosystem management, which would need to include the considerable biological and environmental variation that occurs within the simple black and white patterns we characterized. However, the simplified analysis provides considerable information on the recent rates and major patterns of forest landscape dynamics in this area and has several management implications.

First, as the map of interior forest demonstrates, several large remnant concentrations of interior forest habitat are emerging in the managed landscape. Where management for interior forest habitat is a goal, these concentrations can serve as the foundation of an interior forest habitat network (Noss and Harris 1986). Most of these areas are currently on public lands, such as wilderness and Research Natural Areas, that will not be cut.

Second, if the intervening lands between the interior forest concentrations are to be managed for late successional interior forest habitat, special management practices will be required because much of the area is relatively fragmented. Management for interior forest conditions in the intervening lands will require regrowth of cutover areas while maintaining current interior forest remnants. The process would require delaying or excluding cutting in some areas and concentrating it in other areas. The degree of fragmentation should not be the sole criterion in setting priorities for cutting, however. Although highly fragmented forest areas may be considered ecologically less valuable now, many are in highly productive and species-rich, low-elevation sites or in concentrations of old, diverse forests, where logging started very early. The fragments in these areas could be valuable remnants in a strategy to develop interior forest blocks of mid- to late-successional forest on productive and biologically diverse sites. The current interior forest fragments can also serve as linkages for late-successional organisms moving between large interior forest areas.

Third, the results document that the lower elevation portions of the landscape on private lands will experience higher rates of disturbance and greater proportions of early-successional habitat and species than adjacent public lands. The ecological effects of this juxtaposition of large areas of different forestry land management schemes are not known, but could include mass effects for both animals and plants (Cody 1989). At the scale of the study area, the private lands may act as a source of early successional terrestrial and aquatic species that could disperse into the less frequently disturbed public lands. At a larger scale, the study area is near the center of a human land-use and disturbance gradient that begins to the west of the study area in the urban and agricultural lands of the Willamette Valley and moves through private forest lands into public nonwilderness lands and into wilderness lands at the highest elevations. In this context, the private forest lands could be seen as a buffer against the movement of non-native species and materials from the highly altered non-native aquatic and terrestrial ecosystems of the agricultural and urban lands in the Willamette Valley to the relatively unaltered native ecosystems on public lands.

The patterns of interior forest observed on this portion of private and public lands illustrate the importance of existing conditions in designing future landscape patterns for interior-sensitive species. The development of any plan for managing landscape structure and dynamics will need to identify the opportunities and constraints of existing patterns. Rarely will the manager start with a uniform and clean slateeither a completely intact landscape or a completely cutover landscape. Idealized reserve design systems (Harris 1984) will be useful as a long-term goal, but for the interim, landscape managers will need to practice the art of working with the pattern of what they have inherited from nature and previous managers.

\section{ACKNOWLEDGMENTS}

This project was funded in part by NASA grant number NAGW-1460. The authors would like to give special thanks to Maria Fiorella for help in image and GIS processing. In addition, we would like to thank Bill McComb, Brian Greber, K. Norman Johnson, Janet Ohmann, Fred Swanson, Mark Harmon, Miles Hemstrom, and Jerry Franklin for reviews of an earlier version of this manuscript.

\section{Literature Cited}

Anonymous. 1990. Land and resource management plan. Willamette National Forest. United States Department of Agriculture Forest Service, Pacific Northwest Region, Portland, Oregon, USA.

Brown, E. R., technical editor. 1985. Managment of wildlife and fish habitats in forests of western Oregon and Washington. Part 1 -chapter narratives. United States Forest Service, Pacific Northwest Region, Portland, Oregon, USA.

Chen, J. 1991. Microclimatic and biological pattern at edges of Douglas-fir stands. Dissertation. University of Washington, Seattle, Washington, USA.

Cody, M. L. 1989. Discussion: structure and assembly of communities. Pages 227-241 in J. Roughgarden, R. M. May, and S. A. Levin, editors. Perspectives in ecological theory. Princeton University Press, Princeton, New Jersey, USA.

Curtis, J. T. 1956. The modification of mid-latitude grasslands and forests by man. Pages 721-736 in W. L. Thomas, editor. Man's role in changing the face of the earth. University of Chicago Press, Chicago, Illinois, USA.

Fernside, P. M. 1982. Deforestation in the Brazilian Amazon: how fast is it occurring? Interciencia 7:82-88.

Forsman, E. D., E. C. Meslow, and H. M. Wight. 1984. Distribution and biology of the spotted owl in Oregon. Wildlife Society Monograph 87.

Franklin, J. F., I. Cromack, Jr., W. Denison, A. Mckee, C. Maser, J. Sedell, F. Swanson, and G. Juday. 1981. Ecological characteristics of old-growth Douglas-fir forests. United States Forest Service General Technical Report PNW-118. 
Franklin, J. F., and C. T. Dyrness. 1973. Natural vegetation of Oregon and Washington. United States Forest Service General Technical Report PNW-8.

Franklin, J. F., and R. T. T. Forman. 1987. Creating landscape patterns by forest cutting: ecological consequences and principles. Landscape Ecology 1:5-18.

Grant, G. E. 1990. Hydrologic, geomorphic, and aquatic habitat implications of old and new forestry. Pages 35-53 in A. Pearson and D. A. Challenger, editors. Forests-wild and managed: differences and consequences. University of British Columbia, Vancouver, British Columbia, Canada.

Greber, B. J., K. N. Johnson, and G. Lettman. 1990. Conservation plans for the northern spotted owl and other management proposals in Oregon: the economics of changing timber availability. Forestry Research Laboratory, College of Forestry, Oregon State University, Corvallis, Oregon, USA.

Green, G. M., and R. W. Sussman. 1990. Deforestation history of the eastern rain forests of Madagascar from satellite images. Science 24:212-215.

Hall, F. G., D. B. Botkin, D. E. Strebel, K. D. Woods, and S. J. Goetz. 1991. Large-scale patterns of forest succession as determined by remote sensing. Ecology 72:628-640.

Hamer, T. E. 1988. Home range size of the northern barred owl and northem spotted owl in western Washington. Thesis. Western Washington University, Bellingham, Washington, USA.

Hansen A. J., T. A. Spies, F. J. Swanson, and J. L. Ohmann. 1991. Conserving biodiversity in managed forests. BioScience 41:382-392.

Harris, L. D. 1984. The fragmented forest. University of Chicago Press, Chicago, Illinois, USA.

Iverson L. R., R. L. Graham, and E. A. Cook. 1989. Applications of satellite remote sensing to forest ecosystems. Landscape Ecology 3:131-143.

Johnson, D. R., and J. K. Agee. 1988. Introduction to ecosystem management. Pages 3-14 in J. K. Agee and D. R. Johnson, editors. Ecosystem management for parks and wilderness. University of Washington Press, Seattle, Washington, USA.

Johnson, K. N., J. F. Franklin, J. W. Thomas, and J. Gordon. 1991. Altematives for management of late-successional forests of the Pacific Northwest. Report to the Agriculture Committee and the Merchant Marine and Fisheries Committee of the U.S. House of Representatives. Department of Forest Resources, Oregon State University, Corvallis, Oregon, USA.

Lehmkuhl, J. F., L. F. Ruggiero, and P. A. Hall. 1991. Landscape-scale patterns of forest fragmentation and wildlife richness and abundance in the southern Washington Cascade Range. Pages 425-442 in L. F. Ruggiero, K. B. Aubry, A. B. Carey, and M. H. Huff, technical editors. Wildlife and vegetation of unmanaged Douglas-fir forests. United States Forest Service General Technical Report PNW-285.

Lillesand, T. M., and R. W. Keifer. 1987. Remote sensing and image interpretation. Second edition. John Wiley and Sons, New York, New York, USA

Lovejoy, T. E., J. M. Rankin, R. D. Bierregaard, Jr., K. S. Brown, Jr., L. H. Emmons, and M. E. Van der Voort. 1984 Ecosystem decay of Amazon forest remnants. Pages 295325 in M. H. Nitecki, editor. Extinctions. University of Chicago Press, Chicago, Illinois, USA.

Lubchenco, J., A. M. Olson, L. B. Brubaker, S. R. Carpenter, M. M. Holland, S. P. Hubbell, S. A. Levin, J. A. MacMahon, P. A. Matson, J. M. Melillo, H. A. Mooney, C. H. Peterson, H. R. Pulliam, L. A. Real, P. J. Regal, and P. G. Risser. 1991. The sustainable biosphere initiative: an ecological research agenda. Ecology 72:371-412.

Morrison, P. H., and F. Swanson. 1990. Fire history and pattern in a Cascade Range landscape. United States Forest Service General Technical Report PNW-254.

Nelson, R., N. Homing, and T. A. Stone. 1987. Determining the rate of forest conversion in Mato Grosso, Brazil, using Landsat MSS and AVHRR data. International Journal of Remote Sensing 8:1767-1 784.

Noss, R. F., and L. D. Harris. 1986. Nodes, networks and MUMs: preserving diversity at all scales. Environmental Management 10:299-309.

Ripple, W. J., G. A. Bradshaw, and T. A. Spies. 1991 a. Measuring forest landscape patterns in the Cascade Range of Oregon, USA. Biological Conservation 57:73-88.

Ripple, W. J., D. H. Johnson, K. T. Hershey, and E. D. Meslow. $1991 \mathrm{~b}$. Old-growth and mature forests near spotted owl nests in western Oregon. Joumal of Wildlife Managment 55:316-318.

Ruggiero, L. F., L. C. Jones, and K. B. Aubry. 1991. Plant and animal associations in Douglas-fir forests of the Pacific Northwest: an overview. Pages $447-462$ in L. F. Ruggiero, K. B. Aubry, A. B. Carey, and M. H. Huff, technical editors. Wildlife and vegetation of unmanaged Douglas-fir forests. United States Forest Service General Technical Report PNW-285.

Sader, S. A., and A. T. Joyce. 1988. Deforestation rates and trends in Costa Rica, 1943-1988. Biotropica 20:11-19.

Schonwald-Cox, C. M. 1988. Boundaries in the protection of Nature Reserves. BioScience 38:480-486.

Schoonmaker, P., and A. McKee. 1988. Species composition and diversity during secondary succession of coniferous forests in the westem Cascade Mountains of Oregon. Forest Science 34(4):960-979.

Skole, D., and C. Tucker. 1993. Tropical deforestation and habitat fragmentation in the Amazon: satellite data from 1978 to 1988 . Science $260: 1905-1910$.

Society of American Foresters. 1991. Task force report on biological diversity in forest ecosystems. Society of American Foresters, Bethesda, Maryland, USA.

Soulé, M. E. 1991. Conservation: tactics for a constant crisis. Science 253:744-750.

Spies, T. A., and S. P. Cline. 1988. Coarse woody debris in manipulated and unmanipulated coastal Oregon forests. Pages 5-24 in C. Maser, R. F. Tarrant, J. M. Trappe, and J. F. Franklin, technical editors. From the forest to the ocean-a story of fallen trees. United States Forest Service General Technical Report PNW-229.

Spies, T. A., and J. F. Franklin. 1988. Old growth and forest dynamics in the Douglas-fir region of western Oregon and Washington. Natural Areas Journal 8:190-201.

Spies, T. A., and J. F. Franklin. 1991. The structure of natural young, mature, and old-growth Douglas-fir forests in Oregon and Washington. Pages $91-109$ in L. F. Ruggiero, K. B. Aubry, A. B. Carey, and M. H. Huff, technical editors. Wildlife and vegetation of unmanaged Douglas-fir forests. United States Forest Service General Technical Report PNW-285.

Swanson, F. J., and J. F. Franklin. 1992. New forestry principles from ecosystem analysis of Pacific Northwest forests. Ecological Applications 2:262-274.

Taylor, A. L., and E. D. Forsman. 1976. Recent range extensions of the barred owl in western North America, including the first records for Oregon. Condor 78:560-561.

Thomas, J. W., E. D. Forsman, J. B. Lint, E. C. Meslow, B. R. Noon, and J. Verner. 1990. A conservation strategy for the northern spotted owl: report of the Interagency Scientific Committee to Address the Conservation of the Northern Spotted Owl. U.S. Government Printing Office Document 1990-791-171/20026. Portland, Oregon, USA.

Voous, K. H. 1989. Owls of the northern hemisphere. MIT Press, Cambridge, Massachusetts, USA.

Whitcomb, R. F., C. S. Robbins, J. F. Lynch, B. L. Whitcomb, M. K. Klimkiewicz, and D. Bystrak. 1981. Effects of forest fragmentation on avifauna of the Eastern deciduous forest. Pages 124-205 in R. L. Burgess and D. M. Sharpe, editors. Forest island dynamics in man-dominated landscapes. Springer-Verlag, New York, New York, USA. 